\title{
The Effect of Career Development and Motivation of Employee Performance in Syariah Mandiri Bank Regional III Office Jakarta
}

\author{
Dita Novitayanti ${ }^{1}$, Muhammad Doddy $\mathbf{A B}^{2}$, Nursanita Nasution ${ }^{3}$
}

\author{
${ }^{I}$ SEBI: Email: rd.ditanovianti@gmail.com \\ ${ }^{2}$ SEBI Lecturer \& Doctoral Candidate AeU Malaysia Email: doddy.abe@gmail.com \\ ${ }^{3}$ SEBI Lecturer Email; nursanita1@gmail.com
}

\begin{abstract}
This study aims to examine the effect of career development and motivation on employee performance. This research using quantitative research. Data were obtained by questionnaires to 37 respondents who worked at BSM Region III Office in 2020. The sampling technique in this study is non-probability sampling, with the Partial Least Square (PLS) approach is using a data analysis technique. Based on the results of data analysis, career development has a significant effect on employee performance and motivation has a significant effect on employee performance. Therefore, by providing career development opportunities and motivation for employees will improve employee performance.
\end{abstract}

Keywords: Career Development; Motivation; Employee Performance

\section{INTRODUCTION}

When facing tight competition in the economy, many companies often cannot stand to survive because they are required to make changes. The same thing happens in banking, especially Islamic banking. Competition between banks has an important influence on the strength of a bank to survive. Bank Syariah Mandiri in the 2018 Annual Report taken from the Bank's Publication Financial Report and Sharia Banking Statistics The Financial Services Authority (SPS OJK) recorded the market share of sharia commercial banks in 2018 shown in table 1.1.

Table 1. 1 Sharia Commercial Bank Market Share in 2018

\begin{tabular}{|c|c|c|c|c|c|c|c|}
\hline & & \multicolumn{6}{|c|}{ Market share in 2018 } \\
\cline { 3 - 8 } $\mathrm{N}$ & Bank Umum Syariah & $\begin{array}{c}\text { Ase } \\
\mathrm{t}\end{array}$ & $\begin{array}{c}\text { Pemb } \\
\text { iayaa } \\
\mathrm{n}\end{array}$ & $\begin{array}{c}\mathrm{DP} \\
\mathrm{K}\end{array}$ & $\begin{array}{c}\text { Lab } \\
\mathrm{a}\end{array}$ & $\begin{array}{c}\text { Eku } \\
\text { itas }\end{array}$ & $\begin{array}{c}\text { Base } \\
\mathrm{d} \\
\text { Inco } \\
\text { me }\end{array}$ \\
\hline 1 & Bank Syariah Mandiri & $\begin{array}{c}20, \\
6\end{array}$ & 21,0 & $\begin{array}{c}23, \\
5\end{array}$ & $\begin{array}{c}11, \\
8\end{array}$ & $\begin{array}{c}20, \\
3\end{array}$ & 8,12 \\
\hline
\end{tabular}


46 |Dita Novitayanti, Muhammad Doddy AB, Nursanita Nasution : The Effect of Career Development and Motivation of Employee Performance in Syariah Mandiri Bank Regional III 0ffice Jakarta

\begin{tabular}{|c|l|c|c|c|c|c|c|}
\hline 2 & Bank Muamalat & $\begin{array}{c}12, \\
0\end{array}$ & 10,48 & $\begin{array}{c}12, \\
2\end{array}$ & $\begin{array}{c}2,2 \\
0\end{array}$ & $\begin{array}{c}10, \\
0\end{array}$ & 3,45 \\
\hline 3 & BNI Syariah & $\begin{array}{c}8,6 \\
0\end{array}$ & 8,87 & $\begin{array}{c}9,5 \\
5\end{array}$ & $\begin{array}{c}8,1 \\
3\end{array}$ & $\begin{array}{c}10, \\
7\end{array}$ & 1,22 \\
\hline 4 & BRI Syariah & $\begin{array}{c}7,9 \\
4\end{array}$ & 6,83 & $\begin{array}{c}7,7 \\
6\end{array}$ & $\begin{array}{c}2,0 \\
8\end{array}$ & $\begin{array}{c}12, \\
7\end{array}$ & 1,35 \\
\hline 5 & Bank Aceh Syariah & $\begin{array}{c}4,8 \\
4\end{array}$ & 4,13 & $\begin{array}{c}4,9 \\
5\end{array}$ & $\begin{array}{c}8,5 \\
8\end{array}$ & $\begin{array}{c}5,6 \\
2\end{array}$ & 1,08 \\
\hline 6 & Bank Panin Syariah & $\begin{array}{c}1,8 \\
4\end{array}$ & 1,92 & $\begin{array}{c}1,8 \\
6\end{array}$ & $\begin{array}{c}0,4 \\
1\end{array}$ & $\begin{array}{c}4,2 \\
3\end{array}$ & 0,18 \\
\hline 7 & $\begin{array}{l}\text { Bank Jabar Banten } \\
\text { Syariah }\end{array}$ & $\begin{array}{c}1,4 \\
1\end{array}$ & 1,46 & $\begin{array}{c}1,3 \\
9\end{array}$ & $\begin{array}{c}0,3 \\
3\end{array}$ & $\begin{array}{c}2,1 \\
6\end{array}$ & 0,19 \\
\hline 8 & Bank Syariah Bukopin & $\begin{array}{c}1,3 \\
3\end{array}$ & 1,33 & $\begin{array}{c}1,2 \\
2\end{array}$ & $\begin{array}{c}0,0 \\
4\end{array}$ & $\begin{array}{c}2,2 \\
4\end{array}$ & 0,28 \\
\hline 9 & BTPN Syariah & $\begin{array}{c}2,5 \\
2\end{array}$ & 2,27 & $\begin{array}{c}2,0 \\
5\end{array}$ & $\begin{array}{c}18, \\
8\end{array}$ & $\begin{array}{c}10, \\
1\end{array}$ & 0,01 \\
\hline 10 & Bank Mega Syariah & $\begin{array}{c}1,5 \\
4\end{array}$ & 1,62 & $\begin{array}{c}1,5 \\
3\end{array}$ & $\begin{array}{c}0,9 \\
1\end{array}$ & $\begin{array}{c}3,0 \\
5\end{array}$ & 0,19 \\
\hline 11 & BCA Syariah & $\begin{array}{c}1,4 \\
8\end{array}$ & 1,53 & $\begin{array}{c}1,4 \\
8\end{array}$ & $\begin{array}{c}1,1 \\
4\end{array}$ & $\begin{array}{c}3,2 \\
0\end{array}$ & 0,18 \\
\hline 12 & Maybank Syariah & $\begin{array}{c}0,1 \\
4\end{array}$ & 0,02 & $\begin{array}{c}0,0 \\
0\end{array}$ & $\begin{array}{c}(1,2 \\
)\end{array}$ & $\begin{array}{c}1,3 \\
4\end{array}$ & 0,00 \\
\hline 13 & Bank Victoria Syariah & $\begin{array}{c}0,4 \\
5\end{array}$ & 0,39 & $\begin{array}{c}0,4 \\
0\end{array}$ & $\begin{array}{c}0,1 \\
(0,1\end{array}$ & $\begin{array}{c}0,7 \\
4\end{array}$ & 0,05 \\
\hline 14 & Bank NTB Syariah & $\begin{array}{c}1,4 \\
7\end{array}$ & 1,52 & $\begin{array}{c}1,3 \\
2\end{array}$ & $\begin{array}{c}0,7 \\
5\end{array}$ & $\begin{array}{c}3,3 \\
9\end{array}$ & 0,08 \\
\hline
\end{tabular}

Source: 2018 Syariah Mandiri Bank Annual Report

To be able to maintain and increase customer loyalty, Bank Syariah Mandiri must be able to maintain company performance. The role of human resource management is very important in the company in improving company performance, because company performance depends on the performance of each of its employees. According to (Noe, Hollenbeck, Gerhant, \& Wright, 2010) human resources are the main asset in an organization that must be nurtured and cared for. Organizations without the support of appropriate employees both in quantitative, qualitative terms. Strategies and operations, the organization is unable to maintain its existence, develop and advance in the future (Rivai, 2009).

Many factors can improve performance in organizations. According to (Mangkunegara, 2005) factors that can affect the achievement of performance are the ability and motivation factors. The ability factor is a factor that comes from each employee based on how to complete the task with the expertise they have, while motivation can come from outside or within the employee. Motivation that comes from within is when the individual has the drive to get what he wants, while motivation that comes from outside is based 
on encouragement from other individuals both directly and indirectly so that the individual has the desire to realize his goals.

One factor that can encourage employees to produce optimal performance is career development. According to (Nawawi, 2006) career development is a business that is carried out formally and sustainably with a focus on increasing and increasing the ability of a worker. Career development tools according to (Handoko, 2012) there are three things, namely education, training and experience.

Bank Syariah Mandiri is very concerned about the career development of its employees, each employee has the same right to be able to excel in producing good performance so as to improve his career path. This is supported by the Talent Management program. Talent Management Program is an effort to manage and develop employees, by identifying and developing potential employees, utilizing the strengths and skills of employees based on their performance and potential, in accordance with the needs of the organization used to be able to fill strategic positions in the future, activities in the program These include participating in leadership training and technical knowledge abroad, S2 Education scholarships and participating in leadership development programs.

With career development in the form of a promotion for an employee, employees will get feedback that is high income according to their position. One of the things that motivates employees to work is to get a high income. According to Maslow's theory in (Hariandja, 2009) shows there are five levels of human needs, one of which is physiological needs, namely the need for food, drink, housing, sexual. This need is most basic for humans. In working, the needs of employees that must be met are salaries / decent wages. There is also a need for self-esteem, the need to be respected and valued by others. In this relationship, employees need respect and recognition and are not treated well.

Bank Syariah Mandiri has several ways to motivate employees so that employees feel valued by the company, one of which is Reward Management. Based on the 2018 Bank Syariah Mandiri Annual Report the management of employee rewards is all types of company rewards to employees both directly and indirectly. This approach is the company's effort to create a pleasant, challenging and empowering work environment through the use of their ability to do meaningful work. Rewards are given by prioritizing the principles of competitiveness and fairness where rewards can be given financially such as annual bonuses, health facilities, leave days, employee financing and others. There are also non-financial rewards such as Umrah, throughout 2018 based on the performance of the bank in 2017 has given Umrah appreciation to 365 employees who prioritized employees who will enter retirement. All forms of rewards are adjusted to the ability of the bank and based on bank performance, unit performance and employee performance.

Employee career development is seen from the value of the employee's performance. If the performance value is good then the employee gets a promotion for his career and when the employee has occupied a good 
48 |Dita Novitayanti, Muhammad Doddy AB, Nursanita Nasution : The Effect of Career Development and Motivation of Employee Performance in Syariah Mandiri Bank Regional III 0ffice Jakarta

position, the employee will get feedback in the form of good income according to his performance or position. One of the things that motivates employees to work is to get high income. In addition, by increasing employee performance, it will also increase company productivity.

Based on the results of interviews conducted by researchers with the Human Resources Development (HRD) section of Bank Syariah Mandiri Jakarta Regional Office III, the company realizes that every employee can continue to develop so as to improve his performance of the company, therefore the company provides career opportunities to employees as large as the extent, whether it's a promotion or a change in the concentration of work division. This is done, the possibility of employees with good performance potential can be obtained from promotions or changes to the concentration division, through the Bank Syariah Mandiri Talent Management program to provide opportunities for employees to develop their careers to improve their performance so that they can improve their performance company.

Table 1. 2 Number of Employees Job Level

\begin{tabular}{|c|c|c|}
\hline Level Jabatan & $\mathbf{2 0 1 8}$ & $\mathbf{2 0 1 7}$ \\
\hline Senior Management & 45 & 44 \\
\hline Middle Management & 812 & 804 \\
\hline Officer & 2.976 & 2.738 \\
\hline Staff & 4.862 & 5.244 \\
\hline Non Staff & 15 & 44 \\
\hline Jumlah & $\mathbf{8 . 7 1 0}$ & $\mathbf{8 . 8 7 4}$ \\
\hline
\end{tabular}

Source: Syariah Mandiri Bank Annual Report 2018

Based on table 1.2 it can be seen that employee turnover at job level in 2017 and 2018. A change in the number can indicate that there is a career acceptance of employees in the form of a promotion or recruitment of new employees. Like the level of Staff in 2018 as many as 4,862 experienced a reduction compared to 2017 as much as 5,244, but the opposite is the level above that is Officer where in 2017 there were only 2,738 and increased in 2018 as many as 2,976, so too at the Middle Management level in 2017 as much as 804 and increased in 2018 that is as much as 812. The increasing position received at certain level of office shows the existence of career acceptance by employees of Bank Syariah Mandiri.

In this study, based on the description above, the writer tries to raise this issue, is there an influence on career development and motivation on employee performance at Bank Syariah Mandiri Regional Office III Jakarta.

\section{LITERATURE REVIEW}

\section{a. Islamic Bank}

In the Financial Services Authority Regulation (POJK) Number 24 / POJK.03 / 2015 concerning Products and Activities of Sharia Banks and Sharia 
Business Units. Sharia Bank is a Sharia Commercial Bank (BUS) and Sharia People Financing Bank (BPRS), both of which are referred to in Act Number 21 of 2008, Sharia Banks are banks that carry out their business activities based on sharia principles and by type consist of Sharia Commercial Banks and the Syariah People's Financing Bank.

The basic principles of Islamic banking are based on the Koran and the Sunnah. After a deeper study of the basic philosophy of the operation of an Islamic bank, which animates all transactions, it is based on three principles, namely efficiency, fairness and togetherness. Efficiency refers to the principle of helping each other synergistically to obtain the greatest possible profit / margin. Justice refers to a relationship that is not rigged, sincere, with careful agreement on the proportion of inputs and outputs. Togetherness refers to the principle of mutual assistance and advice to increase mutual productivity (Wibowo, 2005).

In Islamic law which is the basis of Islamic banking practice is the prohibition of usury as the word of Allah SWT in Surah Al-Baqarah verse 275 which means:

"People who eat (take) usury cannot stand but rather as the founding of a person who is possessed by devil because of (pressure) insanity. Their condition is because they say (opinion), actually buying and selling is the same as usury, even though Allah has justified the sale and forbid usury."

Also, a hadith which means:

"It was from Ibn Mas'ud that the Messenger of Allah (PBUH) cursed usurers, who gave food, the two witnesses and the note taker" (Muslim HR).

\section{b. Career development}

Career development is defined as a series of lifelong activities (such as workshops) that contribute to the exploration, stabilization, success, and achievement of one's career (Dessler, 2010). This definition is intended that career development is an ongoing activity that benefits the achievement of one's career.

In an effort to realize the goals of career development in the future, employees must be directed and focused on their work so that employees get a career as planned. As was done by Rasulullah SAW, in his work he always takes into account the future so that all his work is really focused and focused. As in the word of Allah QS. Al-Hasyr verse 18 (Pacsyndra, 2013) which means:

"O you who believe, fear Allah, and let everyone pay attention to what he has done for tomorrow (the hereafter); and fear Allah, surely Allah knows what you are doing ".

At work, employees have been serious and focused in doing their jobs, therefore the company must also provide feedback on what employees 
50 |Dita Novitayanti, Muhammad Doddy AB, Nursanita Nasution : The Effect of Career Development and Motivation of Employee Performance in Syariah Mandiri Bank Regional III 0ffice Jakarta

have done to the company by fulfilling what employees need, namely employee career development.

There are 7 (seven) indicators in career development according to (Handoko, 2012), namely:

1) Educational Background is the suitability of education levels possessed by employees to attend training.

2) Knowledge Insights are knowledge possessed by employees in improving competence.

3) The frequency of training, is a measure that indicates the amount or quantity of the amount or frequency of a training for employees in the company.

4) Certain expertise is the ability to do something about a particular role. This is an ability that can be transferred from one person to another.

5) Working period is about the time that has been taken by an employee in carrying out their duties, during which time a lot of experience and lessons learned.

6) Mastery of knowledge is mastery of abilities related to the breadth and depth of knowledge including understanding of personal and professional development.

7) Skill is an ability and capacity obtained through deliberate, systematic and ongoing effort to smoothly and adaptively carry out complex activities or job functions involving ideas (cognitive skills), things (technical skills), and people (interpersonal skills).

\section{c. Motivation}

According to (Mangkunegara, 2010) states that motivation is formed from the attitudes of employees in dealing with work situations in the company (situation). Motivation is a condition or energy that drives employees to be directed or directed to achieve the goals of the company's organization. The mental attitude of employees who are pro and positive towards work situations is what strengthens their motivation to achieve maximum performance. While (Siagian, 2009) explained that motivation as a driving force that resulted in an employee willing and willing to direct the ability in the form of expertise and skills, energy and time to carry out various activities for which he was responsible and fulfill his obligations in order to achieve the goals and various organizational goals which has been determined beforehand.

Motivation in Islam has several meanings in (Maguni \& Maupa, 2018) namely:

1. The desire to carry out all commands and stay away from all His prohibitions. 
2. Passion in studying religious knowledge.

3. Working hard to get a halal fortune in his blessing.

4. The desire to avoid bad qualities

5. Motivation to protect themselves from polytheism, hypocrisy and kufr.

Thus, motivation should lead to good things, not appropriate if looking for motivation for things that are not in the favor of God, because motivation means "moving", the movement must be self-improvement and achieve better quality for the servants of God (Maguni \& Maupa, 2018).

In the Koran surah At-Taubah verse 105, reads:

"And say: Work ye, Then Allah and His Messenger and the believers will see your work, and you will be returned to (Allah) who knows the unseen and the real, then tells you what you have done."

God Almighty strictly ordered that His servants work, as a basis for looking for sustenance and sustenance, because Allah SWT will provide assistance to His servants who like to work, driven with high motivation, that work in order to be able to meet the needs and desires and as a means to always draw closer only to Allah SWT.

There are 8 (eight) motivational indicators proposed by Mc. Clelland in (Hariandja, 2009), namely:

1) Desire to achieve, employees have high achievement needs, have the desire to work hard in order to obtain responses / feedback on the implementation of their duties.

2) Meet the standards, employees who have the need for high achievement he will have a great desire to be able to succeed in completing work according to established standards.

3) Trying to improve abilities, employees who have high achievement needs have a sense of responsibility towards carrying out a task so that they will try to learn to improve their abilities in order to obtain maximum results.

4) Maintaining friendly personal relationships, employees who have high affiliation needs tend to try to foster very friendly personal relationships.

5) Establishing intimate personal relationships, employees who have high affiliation needs have a genuine concern for interpersonal feelings.

6) Desire to influence colleagues, employees who are motivated by power have a strong desire to influence others directly.

7) Responsible for others, employees who are motivated by power have a strong desire to be responsible for others. 
52 |Dita Novitayanti, Muhammad Doddy AB, Nursanita Nasution : The Effect of Career Development and Motivation of Employee Performance in Syariah Mandiri Bank Regional III 0ffice Jakarta

8) Having authority over others, employees who are motivated by power have a strong desire to make rules to govern others.

\section{d. The performance}

According to (Mangkunegara, 2007) the performance of human resources is work performance or work output (quality) both quality and quantity achieved and produced human resources in a period of time in carrying out their work duties in accordance with the responsibilities given to them. According to (Barry, 2002) performance is how someone has worked compared to a predetermined target. According to (Hasibuan, 2007) performance is the result of work achieved by a person in carrying out his duties on skills, effort, opportunity, experience and sincerity as well as time according to predetermined standards and criteria.

Allah SWT expresses it in the form of rewards and torments related to human performance, which is when humans carry out all the commands that have been given by Allah SWT then Allah will give them merit. But on the contrary, when humans neglect and violate the commands that have been outlined by Allah SWT then Allah will give him punishment and painful torture. As the word of God is explained in several verses of the Qur'an, one of which is in Surah Al-Kahf verses 87-88 which means;

"... Whoever commits wrongdoing, we will punish him, then he is returned to his Lord, then God punishes him with a very harsh punishment. As for those who believe and do good, then he gets the best reward in return ..."

According to (Mangkunegara, 2007) there are 7 (seven) indicators to measure performance, namely:

1) Accuracy in carrying out work means that there is a match between the work plan and the goals or objectives set.

2) Accuracy in carrying out the work means careful and selective in carrying out the work in order to avoid mistakes in completing a job.

3) The success of the work result is a situation where the work done has increased from the previous results.

4) Work Quantity shows that the number of types of work performed at a time so that efficiency and effectiveness can be carried out in accordance with company goals. The indicator of the quantity of work is usually measured through the speed of doing work means assessing the time used to complete the job well.

5) Receiving and carrying out work, responsibility shows how much employees receive and carry out their work.

6) Facilities and Infrastructure, is responsible for the work results as well as facilities and infrastructure that are used as well as work behavior every day. 
7) Cooperation or willingness of employees to participate with other employees vertically and horizontally both inside and outside the work so that it will get better. The indicators of cooperation are usually measured through compactness in working together regularly and neatly, united in dealing with a job.

\section{e. Hypothesis}

Figure 2. 1 Framework for Thinking

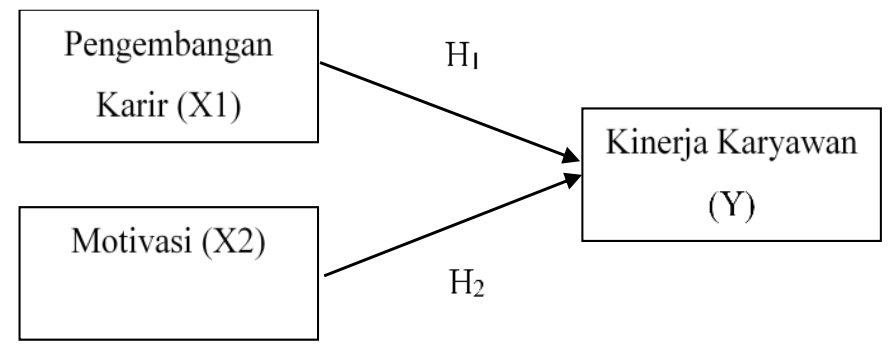

H1: There is a significant influence on career development on employee performance

$\mathrm{H} 2$ : There is a significant effect of motivation on employee performance.

\section{RESEARCH METHODOLOGY}

This research is a type of quantitative causality research. Quantitative research is one of the research methods in which the research data in the form of numbers and analysis using statistics, the goal is to test the hypothesis set. While causality is a type of research in the form of case studies arranged to examine the possibility of a causal relationship between variables (Sugiyono, 2014). In this study, the determination of the sample is done by the Non Probability Sampling Technique which is carried out using the Convenience Sampling Technique, as a collection of information from members of the population that are easily obtained and able to provide that information (Sekaran, 2014). The sample in this study were 37 employees of Bank Syariah Mandiri Jakarta Regional Office. Data obtained by researchers directly from the source or research object in the form of questionnaire answers or questionnaires conducted by giving a set of questions or written statements to respondents to answer (Sugiyono, 2014). The answer to the statement item will be represented by a score which then the score can be processed statistically using a Likert scale. An interview where the researcher asks the things needed in the research to the competent or authorized party to provide information and 
54 |Dita Novitayanti, Muhammad Doddy AB, Nursanita Nasution : The Effect of Career Development and Motivation of Employee Performance in Syariah Mandiri Bank Regional III 0ffice Jakarta

information (Sugiyono, 2014). Literature study is the collection of data by conducting a study of reviews of books, journals, literature, records, data from the internet and so on (Sugiyono, 2014). Data analysis techniques in this study were carried out using the PLS (Partial Least Square) approach using the SmartPLS 3.2.8 application, where this model can test the measurement model (outer model) as well as the structural model (inner model). This study uses the PLS approach because the basic assumption of the writer when using the model is prediction. In addition, PLS can be used to estimate the path model with a smaller sample size (Abdillah \& Jogiyanto, 2015).

\section{ANALYSIS AND DISCUSSION}

\section{a. Evaluation of Measurement Model (Outer Model)}

\section{Convergent validity}

Evaluation of convergent validity starts with checking individual item reliability which can be seen from the standard loading factor value. The loading factor value above 0.7 is said to be ideal which illustrates that the indicator is said to be valid as an indicator that measures constructs. While the loading factor value below 0.7 will be eliminated in the model. The loading factor results can be seen in the following image

Figure 4. 1 Result of Loading Factor Retest 


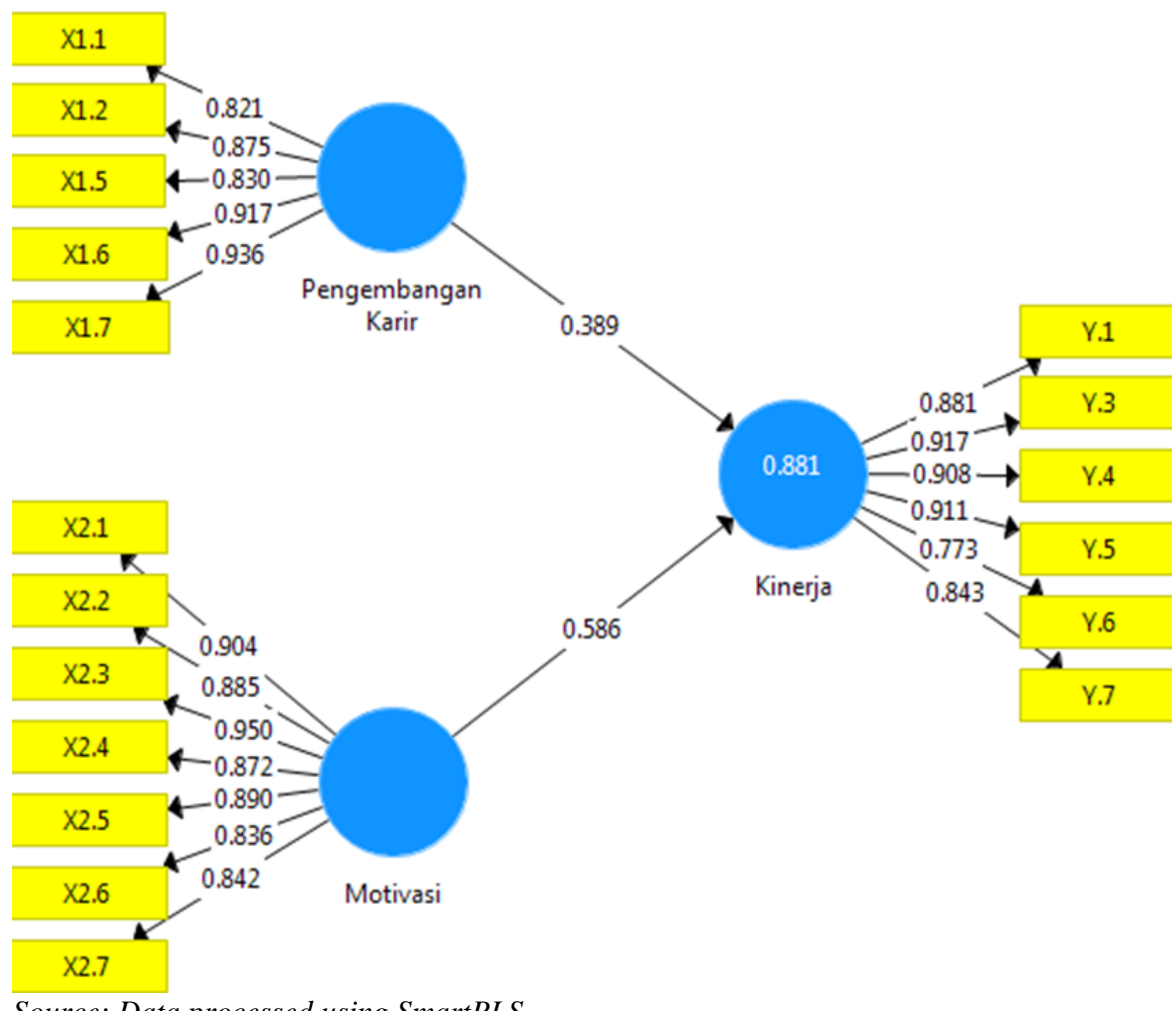

Source: Data processed using SmartPLS

In Figure 4.3, it can be seen that retesting results in loading factor values for all indicators above 0.7 . That way all indicators are declared valid. Furthermore, testing is done by looking at the internal consistency reliability of the composite reliability value. The value of composite reliability is said to be reliable if the value is more than 0.7 . The results of internal consistency reliability can be seen in the following table:

Table 4. 1 Internal Consistency Reliability Test

\begin{tabular}{|c|c|c|c|c|}
\hline Konstrak & $\begin{array}{c}\text { Cronbach' } \\
\text { s Alpha }\end{array}$ & rho_A & $\begin{array}{c}\text { Reliabilita } \\
\text { S } \\
\text { Komposit }\end{array}$ & $\begin{array}{c}\text { Rata-rata } \\
\text { Varians } \\
\text { Diekstrak } \\
\text { (AVE) }\end{array}$ \\
\hline Kinerja & 0.937 & 0.942 & 0.951 & 0.763 \\
\hline Motivasi & 0.953 & 0.954 & 0.961 & 0.780 \\
\hline Pengembangan Karir & 0.924 & 0.930 & 0.943 & 0.769 \\
\hline
\end{tabular}

Source: Data processed using SmartPLS 2020

The results of the test based on table 4.5 show the composite reliability value of each construct namely performance of 0.951 , motivation of 
56 | Dita Novitayanti, Muhammad Doddy AB, Nursanita Nasution : The Effect of Career Development and Motivation of Employee Performance in Syariah Mandiri Bank Regional III Office Jakarta

0.961 , and career development of 0.943 . These results indicate that the value of each construct is above 0.7 so that all constructs can be said to be ideal or reliable.

\section{Discriminant validity}

Reflective models are evaluated through cross loading and AVE squared values with correlation values between constructs. The result of cross loading, if the correlation between indicators with the construct is higher than the correlation with other constructs, this shows that the constructs predict the size of their block better than other blocks. The following cross loading values generated in this study:

Table 4. 2 Results of Discriminant Validity Evaluation through Cross loading

\begin{tabular}{|c|c|c|c|}
\hline & Performance & Motivation & $\begin{array}{c}\text { Career } \\
\text { Development }\end{array}$ \\
\hline $\mathrm{X} 1.1$ & 0.710 & 0.660 & 0.821 \\
\hline $\mathrm{X} 1.2$ & 0.748 & 0.661 & 0.875 \\
\hline $\mathrm{X} 1.5$ & 0.734 & 0.678 & 0.830 \\
\hline $\mathrm{X} 1.6$ & 0.818 & 0.846 & 0.917 \\
\hline $\mathrm{X} 1.7$ & 0.862 & 0.847 & 0.936 \\
\hline $\mathrm{X} 2.1$ & 0.816 & 0.904 & 0.721 \\
\hline $\mathrm{X} 2.2$ & 0.764 & 0.885 & 0.677 \\
\hline $\mathrm{X} 2.3$ & 0.864 & 0.950 & 0.787 \\
\hline $\mathrm{X} 2.4$ & 0.814 & 0.872 & 0.732 \\
\hline $\mathrm{X} 2.5$ & 0.842 & 0.890 & 0.788 \\
\hline $\mathrm{X} 2.6$ & 0.742 & 0.836 & 0.678 \\
\hline $\mathrm{X} 2.7$ & 0.810 & 0.842 & 0.842 \\
\hline $\mathrm{Y} .1$ & 0.881 & 0.822 & 0.833 \\
\hline $\mathrm{Y} .3$ & 0.917 & 0.815 & 0.831 \\
\hline $\mathrm{Y} .4$ & 0.908 & 0.797 & 0.819 \\
\hline $\mathrm{Y} .5$ & 0.911 & 0.839 & 0.854 \\
\hline $\mathrm{Y} .6$ & 0.773 & 0.724 & 0.564 \\
\hline $\mathrm{Y} .7$ & 0.843 & 0.799 & 0.706 \\
\hline
\end{tabular}

Source: Data processed using SmartPLS 2020

Table 4.2 shows that the cross loading value of each indicator for the construct is greater than the cross loading value of the other indicators. This shows that the indicator correlates higher with each construct so that it can be declared to have good discriminant validity. 
Jurnal Ekonomi dan Perbankan Syariah

Vol. 8. No.1, April 2020: 44-62 ISSN (printed): 2355-1755 | ISSN (online): 2579-6437

\section{a. Evaluation of Structural Model (Inner Model)}

\section{Hypothesis Testing Results Through Path Coefficient}

Hypothesis testing is done to test the significant influence of exogenous variables on endogenous variables. Variables are said to have a significant effect if the t-statistic value is greater than the t-table, in this study the $\mathrm{t}$-table is 1.96. To see the results of $\mathrm{t}$-statistics in SmartPLS can be obtained through the results of bootstrapping. The hypothesis is accepted if $\mathrm{t}$-statistics $>$ 1.96 and vice versa, the hypothesis is rejected if t-statistics $<1.96$.

Table 4. 3 Path Coefficient Results

\begin{tabular}{|c|c|c|c|c|c|}
\hline & $\begin{array}{c}\text { Original } \\
\text { Sampel }\end{array}$ & $\begin{array}{c}\text { Sample } \\
\text { Mean }\end{array}$ & $\begin{array}{c}\text { Standard } \\
\text { Deviasi }\end{array}$ & $\begin{array}{c}T \\
\text { Statistics }\end{array}$ & $\begin{array}{c}P \\
\text { Values }\end{array}$ \\
\hline $\begin{array}{c}\text { Career } \\
\text { Development } \rightarrow \\
\text { Performance }\end{array}$ & 0,389 & 0,409 & 0,185 & 2,110 & 0,035 \\
\hline $\begin{array}{c}\text { Motivation } \rightarrow \\
\text { Performance }\end{array}$ & 0,586 & 0,559 & 0,195 & 2,999 & 0,003 \\
\hline
\end{tabular}

Source: Data processed using SmartPLS 2020

Table 4. 4 Comparison of T-Statistics and T-Table

\begin{tabular}{|c|c|c|c|}
\hline Variables & T-Statistics & T-Tabel & Information \\
\hline $\begin{array}{c}\text { Career } \\
\text { Development }\end{array}$ & 2,110 & 1,96 & Has a significant effect \\
\hline Motivation & 2,999 & 1,96 & Has a significant effect \\
\hline
\end{tabular}

Source: Data processed in 2020

From table 4.4, it can be seen that the value of t-statistics obtained on motivation and career development variables is greater when compared to the t-table value of 1.96. These results indicate that career development variables have a significant effect on performance and motivation variables have a significant effect on performance.

\section{Coefficient of Determination}

The coefficient of determination is measured by looking at the value of $\mathrm{R}$ square to see whether the influence of exogenous latent variables on endogenous variables has substantive effects. Based on the results of data processing, obtained $\mathrm{R}$ square size with the following results:

Table 4. 5 Results of R Square Values

\begin{tabular}{|c|c|}
\hline Variabel & R Square \\
\hline Kinerja & 0.881 \\
\hline
\end{tabular}


58 |Dita Novitayanti, Muhammad Doddy AB, Nursanita Nasution : The Effect of Career Development and Motivation of Employee Performance in Syariah Mandiri Bank Regional III 0ffice Jakarta

\section{Source: Data processed using SmartPLS 2020}

Based on table 4.5 above it can be seen that the results of $\mathrm{R}$ Square of 0.881 . This shows that performance can be predicted by career development and motivation by $88.1 \%$. While the remaining $11.9 \%$ is explained by other exogenous variables outside the model under study.

\section{A. Discussion}

\section{Effect of Career Development on Performance}

In this study, career development variables are proxied by seven indicators namely educational background, knowledge insight, training frequency, specific expertise, length of work, mastery of knowledge and skills. In this study all existing indicators pass at the evaluation stage of the measurement model (outer model) so that the indicators used in the study are valid and reliable. Based on the t-statistic table obtained in the career development variable on performance of 2.110 where the value is greater than t-table of 1.96. Thus, it can be concluded that $\mathrm{H} 1$ was accepted. These results indicate that the career development variable has a significant effect on performance where career development has a strong influence on the performance of employees. The higher development opportunities provided to employees will affect the performance of the employees as well.

Career development affects performance, i.e. if a good career development program employees will continue to strive to develop themselves and strive to always meet the needs of the company in order to achieve its objectives, and vice versa. Career development is not only very beneficial for an employee in carrying out his duties, but also for the organization or company as a whole in achieving its goals.

Based on interviews conducted with employees to support statistical results, the following results are obtained:

a. Educational background, this indicator passes the outer model test which means the indicator is valid and reliable. Of the 37 respondents who answered the majority stated "Agree" on this indicator because from the beginning the company made a recruitment of course has special qualifications and administration at several levels of the position so that this educational background will greatly affect the position and career path of the employee later.

b. Knowledge insight, this indicator passes the outer model test which means the indicator is valid and reliable. Of the 37 respondents who answered the majority stated "Agree" on this indicator because in dealing with the world of work, employees will encounter things that might not have been faced before, so broad knowledge will be needed for each individual employee so that employees are ready to face the challenges of the company. 
c. j. The frequency of training, this indicator does not pass the outer model test which means that the indicator cannot measure respondents in the study. Of the 37 respondents who answered that the majority answered "Agree" on this indicator because in addition to supporting employees to have the ability and knowledge to do their jobs properly, the training was also held as a venue for friendship among employees and tightened teamwork.

d. k. Certain expertise, this indicator does not pass the outer model test which means that the indicator cannot measure respondents in the study. Of the 37 respondents who answered the majority stated "Agree" on this indicator because the expertise possessed by employees must be in accordance with the needs of his position so that it can meet the needs of the company, the better the expertise of the employees, the better the performance it produces.

e. 1. Length of work, this indicator passes the outer model test which means the indicator is valid and reliable. Of the 37 respondents who answered the majority stated "Agree" on this indicator because the longer a person works, the more work experience will add.

f. m. Mastery of knowledge, this indicator passes the outer model test which means the indicator is valid and reliable. Of the 37 respondents who answered the majority stated "Agree" on this indicator because the mastery of knowledge for employees is needed to support employees in carrying out their duties.

g. n. Skills, this indicator passes the outer model test which means the indicator is valid and reliable. Of the 37 respondents who answered the majority stated "Agree" on this indicator because skills which are technical abilities will certainly affect employees in completing their tasks such as using a tool or technology.

\section{Effect of Motivation on Performance}

In this study, motivational variables are proxied by eight indicators, namely the desire to achieve, meet standards, try to improve abilities, establish friendly personal relationships, establish intimate personal relationships, the desire to influence colleagues, take responsibility for others and have authority over others. In this study all existing indicators pass at the evaluation stage of the measurement model (outer model) so that the indicators used in the study are valid and reliable. Based on the table t-statistics obtained in the motivation variable on performance of 2.999 where the value is greater than t-table of 1.96. Thus, it can be concluded that $\mathrm{H} 2$ is accepted. These results indicate that the motivation variable has a significant effect on performance where the higher the motivation received by the employee will encourage the employee to improve his performance. Motivation questions how to direct the power and potential of subordinates, so they will cooperate productively and successfully achieve the goals that have been determined. 
Based on interviews conducted with employees to support statistical results, the following results are obtained:

a. The desire to achieve, this indicator passes the outer model test which means the indicator is valid and reliable. Of the 37 respondents who answered the majority stated "Agree" on this indicator because basically every employee wants to excel, therefore to achieve this achievement employees try to continue to improve their performance, not without reason employees want to act because for employees who excel the company will provide rewards in accordance with the ability of the company and the achievement of these employees.

b. Meeting the standard, this indicator passes the outer model test which means the indicator is valid and reliable. Of the 37 respondents who answered the majority stated "Agree" on this indicator because in carrying out their duties, employees are trying to meet applicable standards so that it can be in line with the company's vision and mission.

c. Trying to improve capability, this indicator passes the outer model test which means the indicator is valid and reliable. Of the 37 respondents who answered the majority stated "Agree" on this indicator because they are aware of the increasing challenges of the company, then employees are required to continue to increase their ability to face increasingly fierce company competition so that they can stabilize themselves so that they are worthy to continue working at the company properly .

d. Maintaining friendly personal relationships, this indicator passes the outer model test which means that the indicator is valid and reliable. Of the 37 respondents who answered the majority stated "Agree" on this indicator because the company environment that every day employees and colleagues meet will affect team performance, friendly or good working relationships will make teamwork better.

e. Establishing intimate personal relationships, this indicator passes the outer model test which means that the indicator is valid and reliable. Of the 37 respondents who answered the majority stated "Agree" on this indicator because the company environment that every day employees and colleagues meet will affect team performance, a close working relationship between employees will make teamwork better.

f. The desire to influence coworkers, this indicator passes the outer model test which means the indicator is valid and reliable. Of the 37 respondents who answered the majority stated "Agree" on this indicator because every employee would want to spread the good things they have to coworkers in order to do teamwork that is increasingly aligned.

g. Responsible for others, this indicator passes the outer model test which means the indicator is valid and reliable. Of the 37 respondents who answered the majority stated "Agree" on this indicator because 
in relation to the team or its colleague colleagues, employees have joint responsibility for the work of his team so that each individual will be held accountable to other individuals.

h. Having authority over others, this indicator does not pass the outer model test, which means that the indicator cannot measure respondents in the study. Of the 37 respondents who stated the majority answered "Agree" to this indicator because not all employees have authority over others, this is only owned by a few people or certain positions such as the Human Resources section in managing or controlling their employees.

\section{CONCLUSION}

This study aims to determine the effect of career development and motivation on employee performance. The respondents of this study were 37 employees working at Bank Syariah Mandiri Regional Office III Jakarta. Based on the data that has been collected and testing that has been done on the problem, the following conclusions can be drawn:

1. Career development has a significant effect on the performance of employees of Bank Syariah Mandiri Regional Office III Jakarta. Where career development has a strong influence on the performance of employees. The higher development opportunities that are given to employees will affect the performance improvement of those employees as well.

2. Motivation has a significant effect on the performance of employees of Bank Syariah Mandiri Regional Office III Jakarta. The higher motivation provided by the company to employees will encourage employees to continue to improve their performance towards the company. This means that the employee's performance is also influenced by motivation. 
62 |Dita Novitayanti, Muhammad Doddy AB, Nursanita Nasution : The Effect of Career Development and Motivation of Employee Performance in Syariah Mandiri Bank Regional III 0ffice Jakarta

\section{BIBLIOGRAPHY}

Abdillah, W., \& Jogiyanto. (2015). Partial Least Square (PLS); Struktural Equation Modeling (SEM) dalam Penelitian Bisnis. Yogyakarta: CV. Andi.

Barry, C. (2002). Human Resource Management. Jakarta: PT Elex Media Komputindo.

Dessler, G. (2010). Manajemen Sumber Daya Manusia (Edisi Kese). Jakarta: Indeks.

Handoko, T. H. (2012). Manajemen Personalia dan Sumber Daya Manusia (Edisi Kedu). Yogyakarta: Badan Penerbit Fakultas Ekonomi (BPFE).

Hariandja, M. T. E. (2009). Manajemen Sumber Daya Manusia. Jakarta: PT. Gramedia Sarana Widya Indonesia.

Hasibuan, M. S. P. (2007). Manajemen Sumber Daya Manusia. Jakarta: PT Bumi Aksara.

Maguni, W., \& Maupa, H. (2018). Teori Motivasi, Kinerja, dan Prestasi Kerja dalam Al-Quran Serta Fleksibilitas Penerapannya pada Manajemen Perbankan Islam. Jurna Studi Ekonommi Dan Bisnis Islam, 3(1 juni), $100-124$.

Mangkunegara, A. A. A. P. (2005). Evaluasi Sumber Daya Manusia. Bandung: Refika Aditama.

Mangkunegara, A. A. A. P. (2007). Manajemen Sumber Daya Perusahaan. Bandung: Remaja Rosdakarya.

Mangkunegara, A. A. A. P. (2010). Manajemen Sumber Daya Manusia. Bandung: Remaja Rosdakarya.

Nawawi, H. (2006). Evaluasi Dan Manajemen Kinerja Di Lingkungan Perusahaan Dan Industri. Yogyakarta: Gadjah Mada University Press.

Noe, R. A., Hollenbeck, J. R., Gerhant, B., \& Wright, P. M. (2010). Manajemen Sumber Daya Manusia: Mencapai Keunggulan Bersaing (Edisi 6 Ji). Jakarta: Salemba Empat.

Pacsyndra, S. (2013). Model Pengembangan Karier dalam Upaya untuk Meningkatkan Komitmen Karyawan (Studi pada PT. Ciomas Adisatwa japfa Group Tbk). Universitas Islam Negeri Maulana Malik Ibrahim Malang.

Rivai, V. dan E. J. S. (2009). Manajemen Sumber Daya Manusia Untuk Perusahaan Dari Teori Ke Praktik. Jakarta: Raja Grafindo Persada.

Sekaran, U. (2014). Metodologi Penelitian Untuk Bisnis. Jakarta: Salemba Empat.

Siagian, S. P. (2009). Manajemen Sumber Daya Manusia. Jakarta: Bumi Aksara.

Sugiyono. (2014). Metode Penelitian Kuantitatif, Kualitatif Dan $R \& D$. Bandung: Alfabeta.

Wibowo, E. (2005). Mengapa Memilih Bank Syariah. Bogor: Ghalia Indonesia. 